\title{
Antimicrobial and TNF- $\alpha$ Inhibitory Activity of Barleria prionitis and Barleria grandiflora: A Comparative Study
}

\author{
Hemant Arunrao Sawarkar ${ }^{1 *}$, Pranita P Kashyap ${ }^{1}$, Chanchal Deep Kaur ${ }^{1}$, Ajit Kumar Pandey ${ }^{1}$, Deepak \\ Kumar Biswas', Mukesh Kumar Singh', Hemant Kumar Dhongade ${ }^{1}$
}

${ }^{1}$ Shri Rawatpura Sarkar Institute of Pharmacy, Kumhari, Durg, Chhattisgarh-490042, INDIA.

\begin{abstract}
Background: Leaf juice as well as leaves of Barleria prionitis Linn and Barleria grandiflora Dalz (Acanthaceae) is used by rural people across various regions of India in treatment of oral ailments such as dental troubles, gum ailments, pyorrhoea, dental carries and mouth ulcers. Methods: An antimicrobial activity was carried on aqueous and ethanolic extracts of both herbs and compared with standard chlorhexidine. Cell line study was carried using Human Gingival Fibroblast on ethanolic extracts of leaves of both the herbs and compared with standard marketed preparation Zyrtee. Cytotoxicity and anti gingivitis activity were evaluated using MTT assay. Results of cytokine secretion assay and cytokine measurement assay were analyzed using ANOVA followed by Dunnett multiple comparison test. $P$ values less than 0.05 were considered as significant. Results: Results of antimicrobial activity suggest significant potency for ethanolic extracts of both the herbs. CTC50 values for ethanolic extracts was found to be $848 \mu \mathrm{g} / \mathrm{ml}$ and more than $1000 \mu \mathrm{g} / \mathrm{ml}$ respectively for Barleria prionitis and Barleria grandiflora. The cytokine secretion significantly increased by $S$. mutans control, whereas the cytokine level was reduced in a dose -dependent manner by ethanolic extracts in Streotococcus mutans stimulated HGF cells. The ethanolic extracts EBG and EBP showed 65.31383 \pm $1.087 \%, 75.0425 \pm 1.268 \%$ inhibition of TNF- $\alpha$ at tested concentration respectively. Conclusion: Thus based on findings of this study, we conclude the usefulness of Barleria prionitis and Barleria grandiflora in treatment of oral ailments such as gingivitis.
\end{abstract}

Key words: Barleria prionitis, Barleria grandiflora, Antimicrobial, Cytotoxicity, TNF- $\alpha$ Inhibition.

\section{INTRODUCTION}

Plants are being used for their medicinal values since ancient times. According to $\mathrm{WHO}$ approximately $60-80 \%$ of the world's population still depends on the alternative system of medicine, which largely includes use of plants and plant derived products. ${ }^{1-3}$ Barleria L. (Acanthaceae) is a large, wide spread, pan tropical genus of herbs and shrubs comprising of over 300 species. Its greatest representation is in Africa and Asia, with the greatest centre of diversity in exotic East Africa. ${ }^{4}$ India is represented by 26 to 32 species, one subspecies and one variety. ${ }^{5-7}$ Bar- leria prionitis (BP) Linn, commonly known as vajradanti being used for treatment various ailments by rural population across India. Some uses of the plant and various parts of the plants are in cases of asthma, whooping cough, rheumatism, cough ailment, fever, infection related ailments, neuralgia, snake bite, liver ailments, piles, ulcers, irritation control, wound healing, dropsy, liver congestion, cataract, boils, glandular swellings, stiffness of limbs, sciatica, enlargement of scrotum, increasing vigor, gout, edema, malaria, leucoderma, scabies. ${ }^{8-23}$ Leaves are
Submission Date : 12-02-2016 Revision Date : 28-03-2016 Accepted Date : 24-04-2016

DOI: 10.5530/ijper.50.3.14 Correspondence: Hemant Sawarkar Shri Rawatura Sarkar, Institute of Pharmacy, Kumhari, Durg, Chhattisgarh- 490042, INDIA.

Contact Number: 09893682025

E-mail: mrhemant1979@ gmail.com

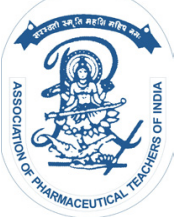

www.ijper.org 
chewed or juices of the leaves are used against toothache, gum ailments, dental troubles and pyorrhea and mouth ulcers. ${ }^{2,8,9,20,24-27}$ Barleria grandiflora (BG) Dalz is another species of this genus, leaves of which are being chewed by rural population across central India for the treatment of mouth ulcer, stomatitis and gingivitis. Literature survey reveals that although these plants and their extracts were evaluated for a number of pharmacological activities, not much of the work has been reported towards their usefulness in oral ailment. The present study aimed to compare the usefulness of leaf extracts of B. prionitis and B.grandiflora in treatment of gingivitis.

\section{MATERIALS AND METHODS}

\section{Plant Material}

The leaves and infloresense of BP and BG (Acanthaceae) were collected from tribal region of Amravati (Maharashtra) in the month of October 2014 and were authenticated by Dr. Mrs. Ranjana Mishra, Professor and Head of Department of Botany, Durg Science College, Durg (Chhattisgarh). Leaves collected from the herbs, dried in shade, powered and used for further work.

\section{Extraction of Plant Material}

The powdered leaves were subjected to de-fatting by petroleum ether. Plant materials thus obtained are further subjected to hot continuous percolation and cold maceration to get ethanolic extracts and aqueous extracts respectively. All the four extracts were then treated with dichloromethane and ethyl acetate subsequently; in order achieve complete removal of fatty material from the plant extracts and designated as EBG (Ethanolic extract of B. grandiflora), EBP (Ethanolic extract of B. prionitis), ABG (Aqueous extract of B. grandiflora) and ABP (Aqueous extract of B. prionitis).

\section{Chemicals and Reagents}

Ethanol (Changshu Hongsheng Fine Chemicals Co. Ltd), Petroleum ether (Molychem), Dichloromethane (Molychem), Ethyl acetate (Molychem) and Nutrient Blood Agar Media (Hi-Media) were procured from Ideal chemicals, Raipur. Phosphate Buffer ( $\mathrm{pH}$ 7.0), DMEM (Dulbecco's Modified Eagle Medium), FBS (Fetal Bovine Serum), serum free media, MTT [3- (4, 5- Dimethyl thiazol 2-yl) - 2, 5- Diphenyl tetrazolium bromide], DMSO (Dimethyl Sulfoxide), standard-Chlorhexidine (antimicrobial activity), marketed preparation zyrtee (Raptakoss Brett) for antigingivitis activity. Chemicals like DMEM, FBS, serum free media, MTT and DMSO (Sigma Aldrich) were used under facilities provided by IVM and Microbiology centre, Research and Development,
Himalaya Drug Company, Makali, Bengalore (India), 562162.

\section{Microorganism}

Cultures of Staphylococcus aureus (MTCC 3160), Streptococcus mutans (MTCC 3160), and Candida albicans (MTCC 890) were procured from IMTECH, Chandigarh. Lactobacillus sporogens (Sporlac powder, Sanzyme (P) Ltd.) was purchased from a local pharmacy outlet (M/s, Gupta Medicals, Kumhari, Durg).

\section{Cell Lines}

HGF cell line (Human Gingival Fibroblast) and L929 cell line (Murine Fibroblast cell line) were utilized from Himalaya Drug Company, Bangalore (India). The cell cytotoxicity study, Cytokine secretion and Cytokine measurement assay were carried out using facilities at IVM and Microbiology, Research and Development, Himalaya Drug Company, Makali, Bengalore (India), 562162.

\section{Antimicrobial Activity}

The intention behind antimicrobial activity was to compare the effectiveness of the extracts against microbial strains and to figure out the most effective extract from the two herbs. The antibacterial activity of the extracts performed against Staphylococcus aureus, Streptococcus mutans, Lactobacillus sporogens and Candida albicans by agar well diffusion method using blood agar nutrient media. $^{31-33}$

\section{Cytotoxicity Assay}

Cytotoxicity of the extracts tested with HGF cells following the methods given by Mossman, ${ }^{34}$ with some modifications. ${ }^{35}$ The HGF cells were seeded $(1 \times 10$ cells $/ \mathrm{ml})$ in 96 well plates in DMEM with high glucose and 10\% FBS and incubated for $24 \mathrm{~h}$ at $37^{\circ} \mathrm{C}$ with $5 \% \mathrm{CO}_{2}$. The initial stock solution of test product $(10 \mathrm{mg} / \mathrm{ml})$ was prepared by dissolving in DMSO and subsequent dilutions made in serum free media, ${ }^{36}$ to obtain the concentration of $1000,500,250,125,62.5,31.25$ and $15.62 \mu \mathrm{g} / \mathrm{ml}$. The dilutions $(100 \mu \mathrm{l} /$ well) were added to HGF cells, and the plate was further incubated at $37 \mathrm{C}$ with $5 \% \mathrm{CO}$. Cell control (DMSO) was also maintained. After 24 hrs incubation, the morphological changes of the cells were observed and cell viability was determined by MTT assay. In MTT assay after $24 \mathrm{~h}$ incubation content of the well were gently removed. $100 \mu \mathrm{l}$ of MTT solution was added into each well and incubated for $4 \mathrm{~h}$ at $37 \mathrm{C}$. After incubation, the cell supernatant was removed gently, and cell monolayer was washed with PBS twice. The cell bound to dye was extracted by adding $100 \mu \mathrm{l}$ of DMSO solution into each well and incubated for $15 \mathrm{~min}$. 
After incubation absorbance was measured using Double beam UV spectrophotometer (UV-1800, Shimadzu) at $540 \mathrm{~nm}$. The \% cytotoxicity was calculated from absorbance values of treated and control groups. The CTC values for the sample were calculated from the dose response curves by linear regression analysis. The non toxic concentration was taken for further experiments.

The $\%$ cytotoxicity was calculated by using following formula:

$$
\% \text { Cytotoxicity }=\{(\mathrm{C} 1-\mathrm{T} 1) / \mathrm{C} 1\} \times 100
$$

Where, $\mathrm{C} 1=$ Absorbance of the control group (DMSO treated) and $\mathrm{T} 1=$ absorbance of the test group.

\section{TNF-a Inhibitory Activity}

In vitro TNF- $\alpha$ Inhibitory Activity (Cytokine secretion and measurement Assay) was carried out by following the method of Uehara et $a^{\beta^{77}}$ with slight modifications. ${ }^{38,39}$ Bacterial strain Streptococcus mutans was used to induce TNF- $\alpha$ secretion in HGF cells. TNF- $\alpha$ secretion in HGF cells. ${ }^{40}$

\section{Cytokines secretion assay}

The HGF cells were seeded $(1 \times 10$ cells $/ \mathrm{ml})$ in $35 \mathrm{~mm}$ petriplate in DMEM with high glucose and $10 \% \mathrm{FBS}$ and incubated for $24 \mathrm{~h}$ at $37 \mathrm{C}$ with $5 \% \mathrm{CO}$. The cells were stimulated with $1 \times 10$ cells $/ \mathrm{ml}$ bacterial strain Streptococcus mutans for inflammatory cytokine secretion (taken as S. mutans control group) and simultaneously the cells were treated with non toxic concentration of the test samples and incubated for $24 \mathrm{~h}$ (test groups). The cells (without addition of $S$. mutans) treated with DMSO (taken as cell control group) were also incubated for 24 hours. After incubation, the cell supernatant was collected to detect the cytokine secretion. The cytokine secretion detected qualitatively by ELISA kit. The effect on percent TNF- $\alpha$ secretion is calculated by using following formula:

$$
\% \mathrm{TNF}-\alpha \text { secretion }=\{(\mathrm{Cs}-\mathrm{Ct}) / \mathrm{Cs}\} \times 100
$$

Where, $\mathrm{Cs}=$ Absorbance of cell control group treated with DMSO.

$\mathrm{Ct}=$ Absorbance of test group/ Absorbance of S. mutans control group.

\section{Cytokines measurement assay}

The L929 cells had been seeded $\left(1 \times 10^{4}\right.$ cells $\left./ \mathrm{ml}\right)$ in 96 well plates in DMEM with low glucose and 10\% FBS and incubated for $24 \mathrm{~h}$ at $37^{\circ} \mathrm{C}$ with $5 \% \mathrm{CO}_{2}$. The HGF cell supernatant was added to L929 cells in the concentration of 1:1 and 1:2 ratios for the detection of TNF- $\alpha$ Cytokine secretion in a dose dependant manner and incubated for $24 \mathrm{~h}$. TNF- $\alpha$ secretion was determined in duplicates by cytotoxicity assay employing MTT.
The percent TNF- $\alpha$ inhibition was calculated by using following formula:

$$
\% \text { Inhibition of TNF- } \alpha=\{\mathrm{Ps}-\mathrm{Pt} / \mathrm{Ps}\} \times 100
$$

Where, Ps $=$ Average percent TNF- $\alpha$ secretion by S. mutans control group.

Pt $=$ Percent TNF $-\alpha$ secretion by test group.

\section{Statistical Analysis}

All the results were expressed as mean \pm standard deviation. Results of cytokine secretion assay and cytokine measurement assay were analyzed using ANOVA followed by Dunnett multiple comparison test. P values less than 0.05 were considered as significant.

\section{RESULTS}

\section{Antimicrobial Activity}

The result of the study shows the significant effectiveness of ethanolic extracts; hence, for further study of cell viability assay, cytokine secretion and inhibition assay ethanolic extracts of both the herbs were used. Among the extracts, EBP was found to be most effective against all test microbes. EBG and EBP have shown comparable zones of inhibition against test microbes. Although the antimicrobial activity of the extracts was found to be lesser but zones of inhibition especially by ethanolic extracts of both the herbs were observed comparable to that of standard Chlorhexidine (Table 1, Figure 1-4).

\section{Cytotoxicity assay by MTT}

Cytotoxic effect of EBG and EBP on HGF cells were assessed using MTT assay. According to the results EBP, EBG at $842.68 \pm 2.1$ and $>1000 \mu \mathrm{g} / \mathrm{ml}$ caused $50 \%$ cytotoxicity to HGF cells respectively (Table 2, Figure 5, 6). The non toxic concentrations of EBP and EBG was further taken for the evaluation of its anti gingivitis activity.

\section{TNF- $\alpha$ Inhibitory assay}

The absorbance values (Table 3) were used to calculate percent $\mathrm{TNF}-\alpha$ secretion. We examined whether EBG and EBP could regulate pro- inflammatory cytokines such as TNF- $\alpha$, in HGF cells. HGF cells were stimulated with $S$. mutans strains for $24 \mathrm{~h}$ to activate cytokine secretion. The cytokine secretion significantly increased by $S$. mutans control, whereas the cytokine level was reduced in a dose- dependent manner by EBG and EBP in $S$. mutans stimulated HGF cells. The results are shown in Table 4, Figure 7. Further, EBG and EBP showed $65.31383 \pm 1.087 \%, 75.0425 \pm 1.268 \%$ inhibition of TNF- $\alpha$ at tested concentration respectively (Table 5, Figure 8). The marketed preparation Zyrtee was used as 


\begin{tabular}{|c|c|c|c|c|c|}
\hline \multirow[t]{2}{*}{ Sample } & \multirow{2}{*}{$\begin{array}{c}\text { Concentration } \\
(\mu \mathrm{g} / \mathrm{ml})\end{array}$} & \multicolumn{4}{|c|}{ Zone of Inhibition (mm \pm S.D.) } \\
\hline & & S. mutans & S.aureus & L. sporogens & C.albicans \\
\hline \multirow[t]{5}{*}{$A B G$} & 100 & $10.38 \pm 0.083$ & $10.14 \pm 0.087$ & 0 & $10.2 \pm 0.1$ \\
\hline & 200 & $11.14 \pm 0.89$ & $10.78 \pm 0.04$ & $10.2 \pm 0.07$ & $11.44 \pm 0.11$ \\
\hline & 400 & $12 \pm 0.07$ & $12.18 \pm 0.1$ & $11.38 \pm 0.083$ & $12.62 \pm 0.83$ \\
\hline & 800 & $12.58 \pm 0.083$ & $14.34 \pm 0.054$ & $13.34 \pm 0.089$ & $14.86 \pm 0.054$ \\
\hline & 1600 & $13.5 \pm 0.07$ & $16.56 \pm 0.04$ & $16.3 \pm 0.01$ & $17.08 \pm 0.083$ \\
\hline \multirow[t]{5}{*}{ EBG } & 100 & $11.42 \pm 0.04$ & $11.16 \pm 0.089$ & $10.28 \pm 0.09$ & $10.82 \pm 0.1$ \\
\hline & 200 & $12.54 \pm 0.054$ & $12.28 \pm 0.083$ & $12.56 \pm 0.054$ & $12.44 \pm 0.07$ \\
\hline & 400 & $13.96 \pm 0.054$ & $13.74 \pm 0.089$ & $14.78 \pm .08$ & $15.775 \pm 0.057$ \\
\hline & 800 & $17.64 \pm 0.054$ & $16.62 \pm 0.01$ & $17.54 \pm 0.11$ & $19.06 \pm 0.057$ \\
\hline & 1600 & $21.12 \pm 0.054$ & $19.7 \pm 0.05$ & $20.16 \pm 0.089$ & $22.6 \pm 0.01$ \\
\hline \multirow[t]{5}{*}{ ABP } & 100 & $10.32 \pm 0.083$ & $10.72 \pm .083$ & $10.4 \pm 0.063$ & $10.5 \pm 0.044$ \\
\hline & 200 & $12.22 \pm 0.1$ & $12.98 \pm .083$ & $11.4 \pm 0.1$ & $12 \pm 0.1$ \\
\hline & 400 & $15.56 \pm 0.089$ & $15.86 \pm 0.048$ & $13.72 \pm 0.083$ & $14.76 \pm 0.48$ \\
\hline & 800 & $19.16 \pm 0.089$ & $17.38 \pm 0.409$ & $14.8 \pm 0.07$ & $17.36 \pm 0.11$ \\
\hline & 1600 & $23.06 \pm 0.089$ & $19.16 \pm 0.054$ & $16.28 \pm 0.083$ & $19.3 \pm 0.1$ \\
\hline \multirow[t]{5}{*}{ EBP } & 100 & $12.18 \pm 0.083$ & $11.2 \pm 0.07$ & $11.5 \pm 0.07$ & $11.3 \pm 0.054$ \\
\hline & 200 & $14.14 \pm 0.083$ & $13.86 \pm 0.054$ & $13.64 \pm 0.11$ & $14.42 \pm 0.109$ \\
\hline & 400 & $17.26 \pm 0.054$ & $17.72 \pm 0.083$ & $18.9 \pm 0.07$ & $18.74 \pm 0.08$ \\
\hline & 800 & $20.56 \pm 0.054$ & $21.14 \pm 0.054$ & $22.5 \pm 0.12$ & $22.48 \pm 0.083$ \\
\hline & 1600 & $25.88 \pm 0.044$ & $24.56 \pm 0.05$ & $25.54 \pm 0.082$ & $26.56 \pm 0.054$ \\
\hline Chlorhexidine & 50 & $28.58 \pm 0.083$ & $29.44 \pm 0.11$ & $29.62 \pm 0.044$ & $28.1 \pm 0.36$ \\
\hline DMSO & 0 & 0 & 0 & 0 & 0 \\
\hline
\end{tabular}

\begin{tabular}{|c|c|}
\hline \multicolumn{2}{|c|}{ Table 2: CTC $_{50}$ values of Leaf extracts } \\
\hline Sample & CTC Values $\mu \mathrm{g} / \mathrm{ml}$ \\
\hline EBP & $842.68 \mu \mathrm{g} / \mathrm{ml}$ \\
\hline EBG & $>1000 \mu \mathrm{g} / \mathrm{ml}$ \\
\hline
\end{tabular}

\begin{tabular}{|c|c|c|c|c|c|c|c|c|}
\hline \multicolumn{7}{|c|}{ Table 3: Absorbance values for TNF-a Inhibitory assay } \\
\hline Sample & $\begin{array}{c}\text { Concentration } \\
(\mu \mathrm{g} / \mathrm{ml})\end{array}$ & $\mathbf{n 1}$ & $\mathrm{n2}$ & $\mathrm{n3}$ & $\mathrm{n4}$ & $\mathrm{n5}$ & $\mathrm{n6}$ & Mean \\
\hline EBG & 400 & 0.557 & 0.565 & 0.559 & 0.587 & 0.567 & 0.552 & 0.5645 \\
\hline & 800 & 0.662 & 0.667 & 0.681 & 0.67 & 0.67 & 0.682 & 0.672 \\
\hline EBP & 400 & 0.625 & 0.67 & 0.659 & 0.66 & 0.68 & 0.678 & 0.662 \\
\hline & 800 & 0.735 & 0.732 & 0.752 & 0.745 & 0.739 & 0.755 & 0.743 \\
\hline Standard & 50 & 0.77 & 0.769 & 0.768 & 0.765 & 0.779 & 0.765 & 0.769333 \\
\hline & 100 & 0.819 & 0.822 & 0.809 & 0.815 & 0.825 & 0.825 & 0.819167 \\
\hline S.mutans control & - & 0.207 & 0.172 & 0.217 & 0.224 & 0.192 & 0.162 & 0.195667 \\
\hline Cell control & - & 0.923 & 0.927 & 0.925 & 0.921 & 0.928 & 0.926 & 0.925 \\
\hline
\end{tabular}

(DMSO treated group was taken as cell control group). 


\begin{tabular}{|c|c|c|c|c|c|c|c|}
\hline \multicolumn{7}{|c|}{ Table 4 \%TNF- $\alpha$ secretion over S. mutans control } \\
\hline & $\begin{array}{c}\text { Concentration in } \boldsymbol{\mu g} / \mathrm{ml} \\
\text { S.m. control }\end{array}$ & $\begin{array}{c}\text { EBG 800 + } \\
\text { S.m. control }\end{array}$ & $\begin{array}{c}\text { EBP 400 + S.m. } \\
\text { control }\end{array}$ & $\begin{array}{c}\text { EBP 800 + } \\
\text { S.m. control }\end{array}$ & $\begin{array}{c}\text { STANDARD50 + } \\
\text { S.m. control }\end{array}$ & $\begin{array}{c}\text { STANDARD100 + } \\
\text { S.m. control }\end{array}$ & S.m. control \\
\hline n1 & 39.78 & 28.43 & 32.43 & 20.54 & 16.76 & 11.46 & 77.62 \\
\hline n2 & 38.91 & 27.89 & 27.56 & 20.86 & 16.87 & 11.14 & 81.4 \\
\hline n3 & 39.57 & 26.37 & 28.75 & 18.703 & 16.97 & 12.54 & 76.54 \\
\hline n4 & 36.54 & 27.57 & 28.64 & 19.46 & 16.97 & 11.89 & 75.78 \\
\hline n5 & 38.7 & 27.56 & 26.48 & 20.11 & 17.29 & 10.81 & 79.24 \\
\hline n6 & 40.32 & 26.27 & 26.7 & 18.38 & 17.29 & 10.81 & 82.48 \\
\hline Mean & 38.97 & 27.34833 & 28.42667 & 19.6755 & 17.025 & 11.44166667 & 78.84333 \\
\hline S.D. & 1.328 & 0.8576 & 2.177 & 1.001 & 0.2194 & 0.6777 & 2.687 \\
\hline P value & $<0.001 \mathrm{a}$ & $<0.001 \mathrm{~b}$ & $<0.001 \mathrm{c}$ & $<0.001 \mathrm{~d}$ & $<0.001 \mathrm{e}$ & $<0.001 \mathrm{f}$ & - \\
\hline
\end{tabular}

Here S. m. means Streptococcus mutans cell control group (P values as indicated in the table are all observed values where S. $\mathrm{m}$. control was taken as control group for Dunnett multiple comparison test).

\begin{tabular}{|c|c|c|c|c|c|c|}
\hline & \multicolumn{6}{|c|}{ Concentration in $\mu \mathrm{g} / \mathrm{ml}$} \\
\hline & $\begin{array}{l}\text { EBG } 400+ \\
\text { S.m. control }\end{array}$ & $\begin{array}{l}\text { EBG } 800+ \\
\text { S.m. control }\end{array}$ & $\begin{array}{l}\text { EBP } 400+ \\
\text { S.m. control }\end{array}$ & $\begin{array}{l}\text { EBP } 800+ \\
\text { S.m. control }\end{array}$ & $\begin{array}{l}\text { STANDARD50 + } \\
\text { S.m. control }\end{array}$ & $\begin{array}{l}\text { STANDARD } 100+ \\
\text { S.m. control }\end{array}$ \\
\hline $\mathrm{n} 1$ & 49.54 & 63.94 & 58.866 & 73.947 & 78.742 & 85.46 \\
\hline $\mathrm{n} 2$ & 50.647 & 64.625 & 65.043 & 73.541 & 78.602 & 85.87 \\
\hline n3 & 49.81 & 66.553 & 63.534 & 76.27 & 78.475 & 84.094 \\
\hline $\mathrm{n} 4$ & 53.65 & 65.043 & 63.673 & 75.317 & 78.475 & 84.919 \\
\hline n5 & 50.91 & 65.043 & 66.413 & 74.493 & 78.07 & 86.289 \\
\hline n6 & 48.858 & 66.679 & 66.134 & 76.687 & 78.07 & 86.289 \\
\hline Mean & 50.56917 & 65.31383 & 63.94383 & 75.0425 & 78.40566667 & 85.48683333 \\
\hline Standard deviation (SD) & 1.684 & 1.087 & 2.761 & 1.268 & 0.2781 & 0.8599 \\
\hline$P$ value & $<0.001 a$ & $<0.001 b$ & $<0.001 c$ & $<0.001 \mathrm{~d}$ & $<0.001 \mathrm{e}$ & - \\
\hline
\end{tabular}

(Calculations are made by subtracting values of \% TNF secretion by test group from the average \% TNF- $\alpha$ secretion by S. mutans control group. Hence, $\%$ TNF- $\alpha$ inhibition by $\mathrm{S}$. mutans control group is not of any significance. P values as indicated in the table are all observed values where all test groups were compared with STANDARD $100+$ S. m. control for Dunnett multiple comparison test).

positive control, which showed $85.49 \pm 0.8599 \%$, inhibition of TNF- $\alpha$, respectively. The results of ethanolic extracts of both the herbs were found to be statistically significant $(\mathrm{P}$ value $<0.001$ ) as compared with standard marketed preparation.

\section{DISCUSSION}

The study was undertaken to authenticate the use of Barleria prionitis and Barleria grandiflora in treatment of oral ailments such as gingivitis, stomatitis and mouth ulcer by rural people across some regions of India. Therapeutic treatments of mouth ulcer include use of anti-inflammatory agents, immunomodulatory agents, antibiotics and others. Micro-organisms are known to cause a wide range of oral infections such as dental caries, periodontal diseases, and peri-implant diseases due to the formation of biofilm. ${ }^{41,42}$ In vitro antimicrobial activities were carried out against oral pathogens Staphylococcus aureus, Streptococcus mutans, Lactobacillus sporogens and Candida albicans. The result of the study shows the significant effectiveness of ethanolic extracts; hence, for further study of cell viability assay, cytokine secretion and inhibition assay ethanolic extracts of both the herbs were used. Cytotoxicity assay was assessed by MTT assay and CTC values for EBP and EBG were found to be $842.68 \mu \mathrm{g} / \mathrm{ml}$ and $>1000 \mu \mathrm{g} / \mathrm{ml}$ suggesting more cytotoxic nature of EBP than EBG. Subsequently, concentrations of $400 \mu \mathrm{g} / \mathrm{ml}$ and $800 \mu \mathrm{g} / \mathrm{ml}$ of both the extract was subjected for cytokine measurement assay where $\%$ inhibition of TNF- $\alpha$ Secretion was calculated and compared to the standard. Pro-inflammatory mediators like TNF- $\alpha$, IL- $1 \beta$ and prostaglandins plays a key role in destruction of periodontal tissues thereby 

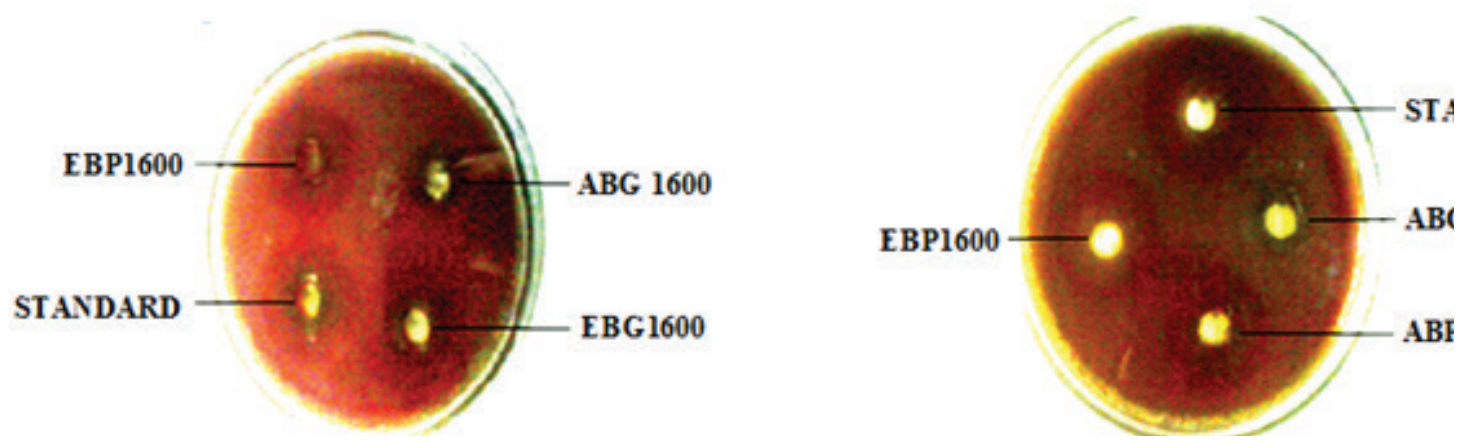

Figure 1: Antibacterial activity of BP and BG against S. mutans.
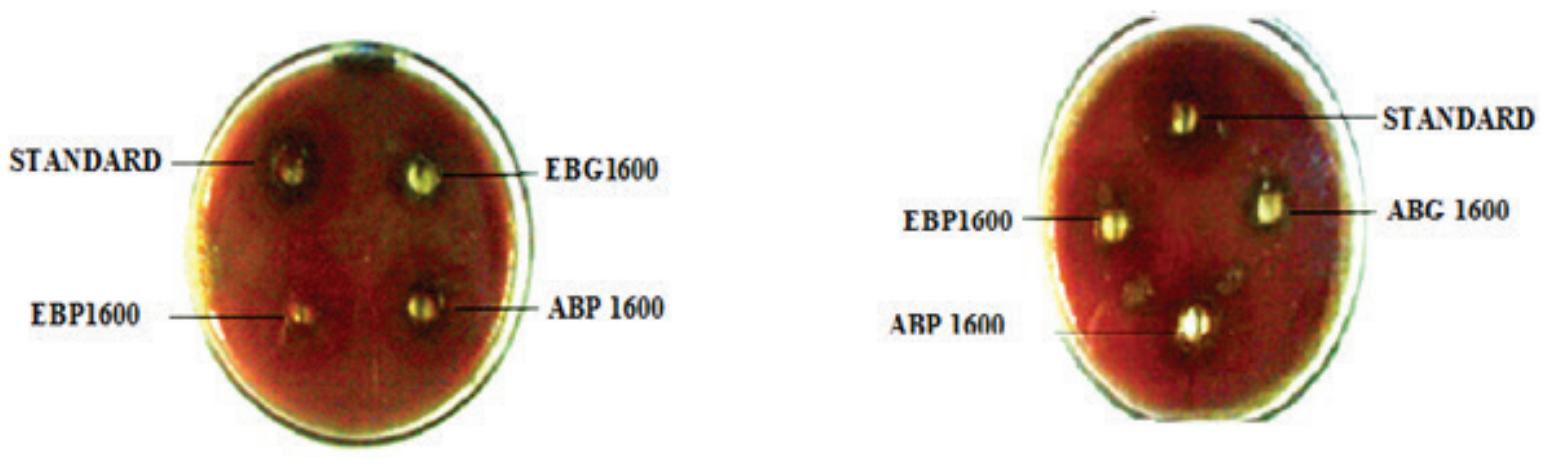

Figure 2: Antibacterial activity of BP and BG against S. aureus.
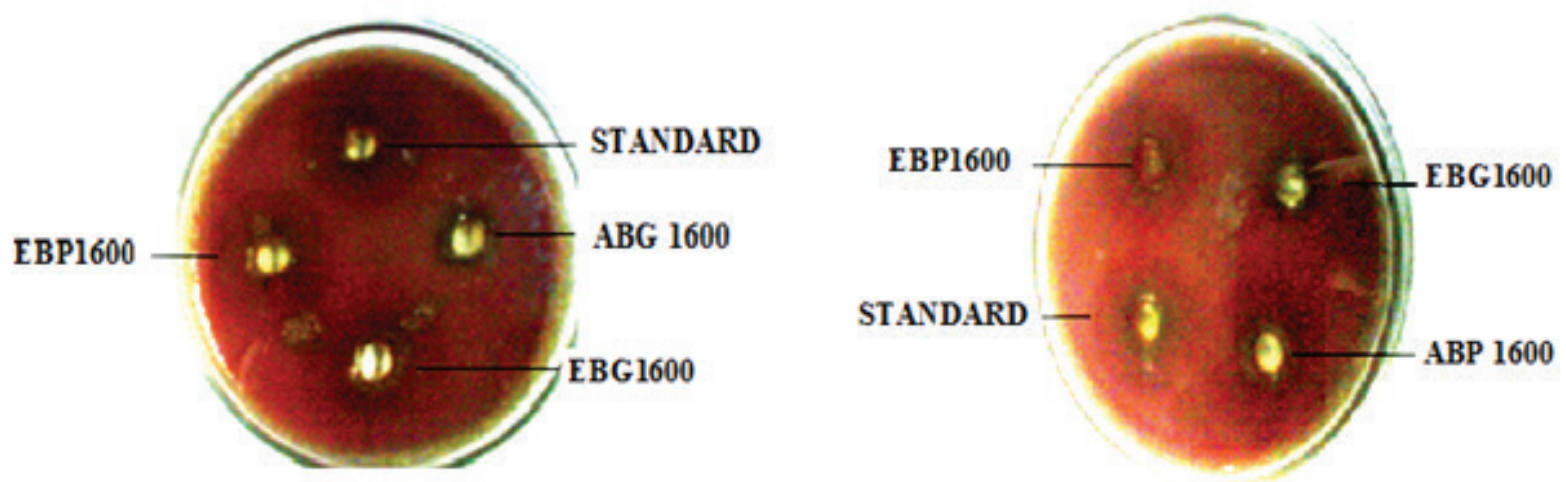

Figure 3: Antibacterial activity of BP and BG against $L$. sporogens.
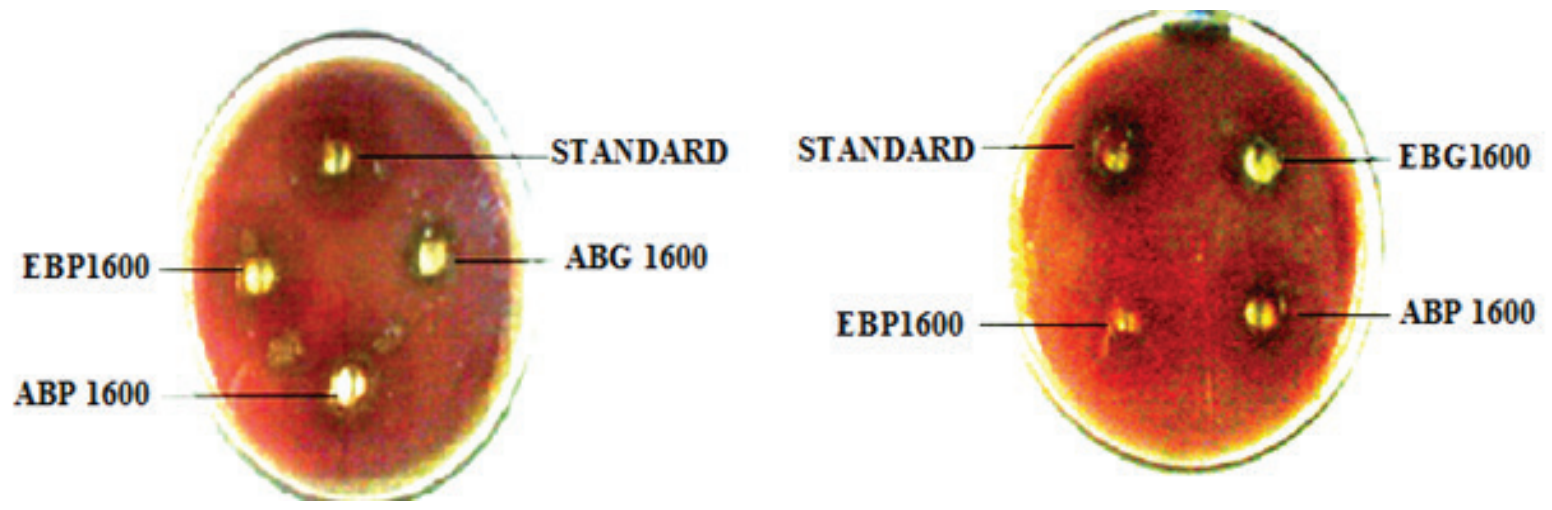

Figure 4: Antifungal activity against of BP and BG against C.albicans. 


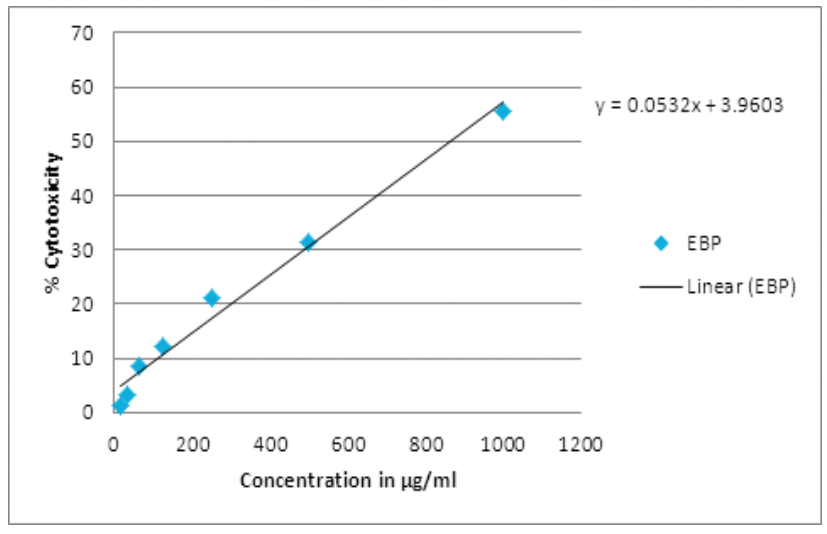

Figure 5: Cytotoxicity of EBP on HGF cells by MTT.

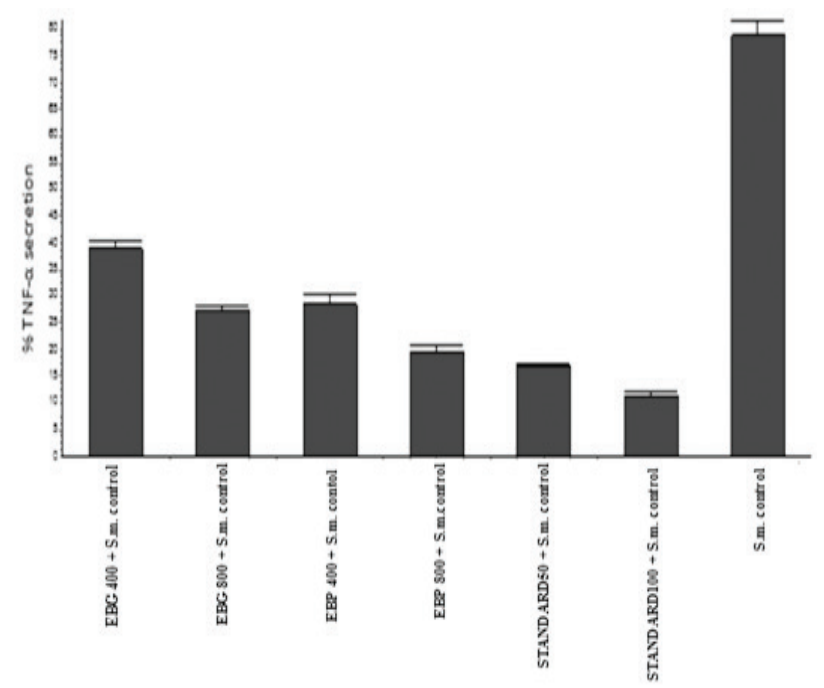

Figure7: Effect on TNF-a secretion over S. mutans control (DMSO treated group was taken as control group, hence not indicated in graph).

causing gingivitis, buccal ulcers and stomatitis. ${ }^{43-45}$ EBP and $\mathrm{EBG}$ were found to be inhibiting TNF- $\alpha$ secretion in a dose-dependent manner and significant $(\mathrm{P}<0.001)$. $\mathrm{EBP}$ was found to be more effective and significant than EBG when compared to that of standard. Barleria prionitis is reported to have chemical constituents to name few are Scutellarein-7-rhamnosyl glucoside, Barlerin, Acetyl Barlerin, luteolin-7-O- $\beta$-D-glucoside, shanziside methyl ester, 6-O-trans-p-coumaroyl-8-O-acetyl shanziside methyl ester, Lupilinoside7-methoxy diderroside, 1 , 8-dihydroxy- 2, 7- dimethyl 3, 6-dimethoxy anthraquinone and 1,3, 6, 8- tetra methoxy- 2, 7-dimethyl anthraquinone. ${ }^{14,46-52}$ Barleria grandiflora has been reported to have phytochemicals like glycosides, anthraquonone, saponins, flavanoids and phenolic compounds. ${ }^{28-30}$ It will

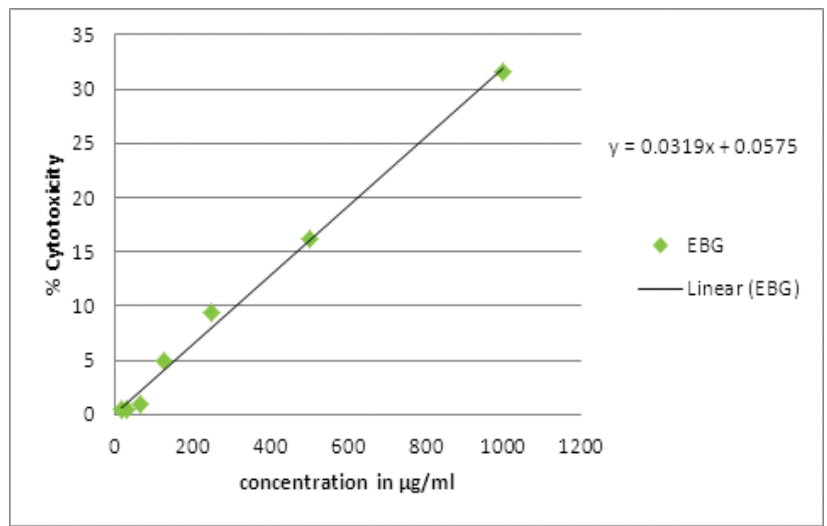

Figure 6: Cytotoxicity of EBG on HGF cells by MTT.

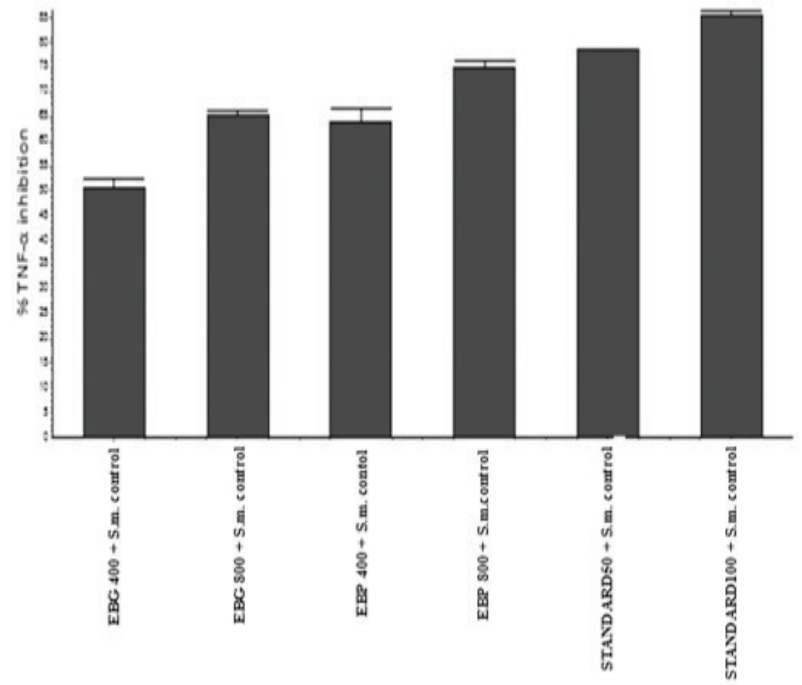

Figure 8: \% TNF-a inhibition over S. mutans control (Calculations are made by subtracting values of $\%$ TNF secretion by test group from the average \% TNF-a secretion by S. mutans control group. Hence, \% TNF-a inhibition by S. mutans control group is not of any significance).

be interesting to relate the current findings of the herbs to the phytoconstituents for which further study is ongoing. Thus based on findings of this study, Barleria prionitis and Barleria grandiflora were found to be showing antimicrobial activity and TNF- $\alpha$ inhibitory activity in treatment of oral ailments such as gingivitis.

\section{ACKNOWLEDGEMENT}

We would like to thank the management of Shri Rawatpura Sarkar Institute of Pharmacy for providing the facilities required during the research.

\section{CONFLICT OF INTEREST}

We declare no conflict of interest. 


\section{ABBREVIATION USED}

BG: Barleria grandiflora; BP: Barleria prionitis; EBG: Ethanolic extract of Barleria grandiflora; EBP: Ethanolic extract of Barleria prionitis; ABG: Aqueous extract of Barleria grandiflora; ABP: Aqueous extract of Barleria prionitis; HGF cell line (Human Gingival Fibroblast); L929 cell line (Murine Fibroblast cell line); DMEM: (Dulbecco's Modified Eagle Medium); FBS: (Fetal Bovine Serum), MTT: (3- (4, 5- Dimethyl thiazol 2-yl) - 2, 5Diphenyl tetrazolium bromide); DMSO: (Dimethyl Sulfoxide), TNF- $\alpha$ : (Tumour necrosis factor- $\alpha$ ).

\section{REFERENCES}

1. Banerjee D, Maji AK, Mahapatra S and Banerji P. Barleria prionitis Linn: A review of its traditional uses, phytochemistry, pharmacology and toxicity. Res J Phytochem. 2012;6(2):31-41.

2. Singh A and Dubey NK. An ethnobotanical study of medicinal plants of Sonebhadra district of Uttar Pradesh, India with reference to their infection by foliar fungi. J Med Plant Res. 2012;6(14):2727-46.

3. Rawat AKS, Shukla AN and Srivastava S. An ethnobotanical study of medicinal plants of Rewa district of Madhya Pradesh. Indian J Traditional Knowledge. 2010;9(1):191-202.

4. Balkwill MJ and Balkwill K. A preliminary analysis of distribution pattern in a large, pantropical genus, Barleria L. (A can thaceae). J Biogeography. 1998;25:95-110.

5. Shendage SM and Yadav SR. Revision of the genus Barleria (Acanthaceae) in India. Rheedea. 2010;20(2):81-130.

6. Karthikeyan S, Sanjappa M and Moorthy S. Acanthaceae. In: Flowering Plants of India-Dicotyledons (Acanthaceae-Avicenniaceae). Botanical Survey of India, Kolkata. 2009;(1):1-62.

7. Balkwill MJ and Balkwill K. Delimitation and infra-generic classification of Barleria (Acanthaceae). Kew Bull. 1997;52(3):535-73.

8. Alam MM and Anis M. Ethno medicinal uses of plants growing in the Bulandshahar district of Northern India. J Ethnopharmacol. 1987;19(1):85-8.

9. Mahajan SK. Traditional herbal remedies among the tribes of Bijagarh of West Nimar district, Madhya Pradesh. Indian J Traditional Knowledge. 2007;6(2):375-7.

10. Singh AK, Raghubanshi AS and Singh JS. Medical ethnobotany of the tribals of Sonaghati of Sonabhadra district, Uttar Pradesh, India. J Ethnopharmacol. 2002;81(1):31-41.

11. Kala CP. Ethno medicinal botany of the Apatani in the Eastern Himalayan region of India. J Ethnobot Ethnomed. 2005;1(1):1.

12. Chirinjibi P, Reddy CS, Das R and Reddy PM. Traditional medicinal practices among the tribal people of Malkangiri district, Orissa, India. Nat Prod Rad. 2007;6(5):430-5.

13. Jadhav D. Ethno medicinal plants used by Bhil tribe of Bibdod, Madhya Pradesh. Indian J Traditional Knowledge. 2006;5(2):263-7.

14. Kosmulalage KS, Zahid S, Udenigwe CC, Akhtar S, Ata A and Samarsekara R. Glutathione S-transferase and acetyl cholinesterase-inhibiting and antibacterial activities of chemical constituents of Barleria prionitis. Z Naturforsch. 2007;62b:580-586.

15. Karruppusamy S.Medicinal plants used by Paliyan tribes of Sirumalai hills of Southern India. Nat Prod Rad.2007;6(5):436-42.

16. Amoo SO, Finnie JF and Staden J Van. In vitro Pharmacological evaluation of three Barleria species. J Ethnopharmacol. 2009;121:274-77.

17. Patil SB, Naikwade NS, Kondawar MS, Magdum CS and Awale VB. Traditional uses of some plants for wound healing in the Sangli district, Maharashtra. Int J Pharm Tech Res. 2009;1(3):876-8.

18. Bhuvaneshwar U, Praveen AKD and Ashwani K. Ethno medicinal and ethnopharmaco statistical studies of Eastern Rajasthan, India. J Ethnopharmacol. 2010;129(1):64-86.
19. Sankaranarayanan S, Bama P, Ramachandran J, Kalaichelvan PT, Deccaraman M, Vijayalakshimi M and Bama SS. Ethnobotanical study of medicinal plants used by traditional users in Villupuram district of Tamil Nadu, India. J Med Plant Res. 2010;4(12):1089-101.

20. Reddy KN, Trimurthulu $G$ and Reddy CS. Medicinal plants used by ethnic people of Medak district, Andhra Pradesh, India. Indian J Traditional Knowledge. 2010;9(1):184-90.

21. Rout SD and Panda SK. Ethno medicinal planter sources of Mayurbhanj district, Orissa. Indian J Traditional Knowledge. 2010;9(1):68-72.

22. Brijesh S, Falguni $S$ and Minoo P. Documenting Grandma's prescriptions for skin ailments in Valsad district, Gujrat. Indian J Traditional Knowledge. 2011;10(2):372-4.

23. Ghanapanadi SR, Johnson $\mathrm{N}$ and Rajasab AH. Documentation of folk knowledge on medicinal palnts of Gulbarga district, Karnataka. Indian J Traditional Knowledge. 2011;10(2):349-53.

24. Katewa SS and Galav PK. Traditional herbal medicines from Shekhawati region of Rajasthan. Indian J Traditional Knowledge. 2005;4(3):237-45.

25. Shukla P, Singh A, Gawri S, Alexander A and Sonwane S. In vitro propagation of Barleria prionitis Linn. And its antibacterial activity. Int J Pharma Prof Res. 2011;2:198-200.

26. Salve AP. Traditional oral healthcare practices in Pathardi areas of Ahmednagar district, Maharashtra, India. Bull Environ Pharmacol Life Sci. 2012;1(7):84-8.

27. Sonawane VB, Saler RS, Sonawane MD and Kadam VB. Ethnobotanical studies of Mokhada, district Thane. Int J Life Sci Pharma Res. 2012;2(1):88-93.

28. Sawarkar HA, Khadabadi SS, Wandhare MD, Farooqui IA and Deokate UA. The antioxidant activity of the leaves of Barleria grandiflora Dalz (Acanthaceae). Ethnobotanical Leaflets. 2009;13:443-9.

29. Salunkhe NB, Kadam AP, Aparadh VT and Chavan JJ. Comparative study of photosynthetic pigments and phenolic content in three Barleria species. World J Pharm Res. 2013;2(3):626-30.

30. Jayanthi MK, Kumar S, Naidu S, Manjula SN and Mruthunjaya K. A study to evaluate the anticancer activity of Barleria grandiflora Dalz (BG). World J Pharm Res. 2014;3(10):788-800.

31. Ahmad L, Mohammad Z and Mohammad F. Screening of Some Indian medicinal plants for their antimicrobial properties. J Ethnopharmacol. 1998;62(2):183-93.

32. Perumalsamy $R$ and Ignacimuthu S. Antibacterial activity of some folklore medicinal plants used by tribals in Western Ghats of India. J Ethnopharmacol. 2000;69(1):63-71.

33. Werner F, Okemo P and Ansorg R. Antibacterial activity of East African medicinal plants .J Ethnopharmacol. 1999;60(1):63-71.

34. Mossmann T. Rapid colorimetric assay for cellular growth and survival: Application to proliferation and cytotoxicity assays. J Immunology Methods. 1983;65(1-2):55-63.

35. Rodanant P, Surarit R, Srichan R, Korsuwanwong S. Cytotoxic and antiinflammatory activity of some Thai medicinal plants. J Med Plant Res. 2012;6(23):4063-8.

36. Anand G, Ravinathan M, Basaviah R and Shetty AV. In vitro antimicrobial and cytotoxic effects of Anacardium occidentale and Mangifera indica in oral care. J Pharm Bioall Sci. 2015;7(1):69-74.

37. Uehara A, Sugawara S and Takada H. Priming of human oral epithelial cells by interferon- to secrete cytokines in response to lipopolysaccharides, lipotechoic acids and peptidoglyacans. J Med Microbiol. 2002;51(8):626-34.

38. Spratt DA, Doglia M, Papetti A, Stauder M, O'Donell D, Ciric L, Tymon A et al. Evaluation of fungal and plant extracts for their potential and anticaries activity. J Biomed Biotech. 2012;1-12.

39. Yao Xin, Chen Nan, Maa Chun-Hua, Tao Jing, Bao Jian-An, Cheng ZongQi. et al. Ginkgo biloba attenuate lipopolysaccharides induced inflammatory responses in acute lung injury by inhibiting the COX-2 and NF-KB pathways. Chinese J Nat Med. 2015;13(1):0052-8.

40. Deutsch ME, Pini A, Yamashita Y, Shibata Y, Hekel Y, Guinard MS and Klein JP. Insertional inactivation of pac and $\mathrm{rml} B$ genes reduces the release of Tumor necrosis factor alpha, Interleukin- 6 and interleukin- 8 induced by Streptococcus mutans in mocytic dental pulp and periodontal ligament cells. Infect Immunol. 2003;71(9):5162.

41. Filoche $\mathrm{S}$, Wong $\mathrm{L}$ and Sissons $\mathrm{CH}$. Oral biofilms: Emerging concepts in microbial ecology. J Dental Res. 2010;89:8-18. 
42. Drouet C, Shakhnov AN and Jongeneel CV. Enhancers and transcription factors controlling the inducibility of the tumor necrosis factor- alpha promoter in primary macrophages. J Immunol. 1991;147(5):1694-700.

43. Dinnarello CA, Gelfand JA and Wolf SA. Anticytokine strategies in the treatment of systemic inflammatory response syndrome. JAMA. 1993;269(14):1829-35.

44. Agarwal S, Piesco NP, Johns LP and Riccelli AE. Differential expression of IL-1 $\beta$, TNF- $\alpha$, IL- 6 and IL- 8 in human monocytes in response to lipopolysaccharides from different microbes. J Dental Res. 1995;74(4):1057-67.

45. Taneja SC and Tiwari. Structures of two new iridoids from Barleria prionitis Linn. Tetrahedron Letters. 1975;16(24):1995-8.

46. Soren D, Soren RJ and Bent JN. Structural revision of barlerin and acetyl barlerin. Tetrahedron Letters. 1982;23(40):4155-6.

47. Gupta HM and Saxena VK. A new acylated luteolin-7-O- $\beta-D-g l u c o s i d e$ from the roots of Barleria prionitis (Linn.). Nat Acad Sci Letter. 1984;7(6):187-9.
48. Chen JL, Blanc P, Stoddart CA, Bogan M and Rozhon EJ. New iridoids from the medicinal plant Barleria prionitis with potent activity against respiratory syncytial virus. J Nat Product. 1998;61(10):1295-7.

49. Singh B, Chandan BK, Prabhakar A, Taneja SC and Qazi GN. Chemistry and hepatoprotective activity of an active fraction from Barleria prionitis Linn. In experimental animals. J Ethnopharmacol. 2005;85:187-93.

50. Ata A, Kalhari KS and Samarsekera R. Chemical constituents of Barleria prionitis and their enzyme inhibitory and free radical scavenging activities. Phytochemistry Letter. 2009;2(1):37-44.

51. Ata SA, Van Den Bosch, Harwanik DJ and Pidwinski GE. Glutathione S-transferase and acetyl cholinesterase-inhibiting natural products from medicinally important plants. Pure Appl Chem. 2007;79(12):2269-76.

52. Ganga Raju SV, Naidu KC, Chakradhar V and Prasad RY. Anthraquinones from Barleria prionitis. Indian Drugs. 2002;39:400-1.

\section{PICTORIAL ABSTRACT}

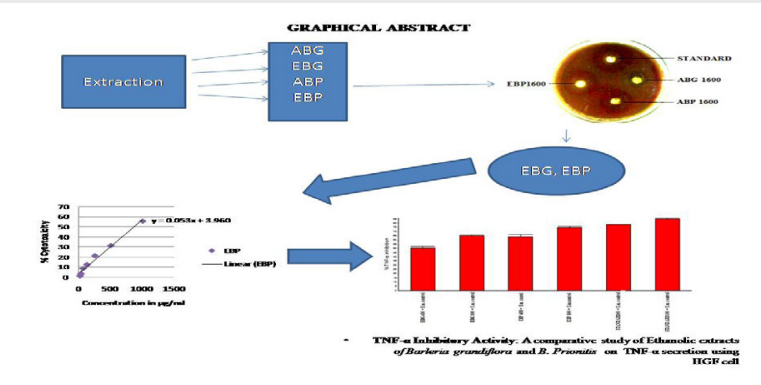

\section{SUMMARY}

- Barleria prionitis and Barleria grandiflora used in treatment of oral ailments by rural population across India.

- Antimicrobial activity suggested efficacy of ethanolic extracts.

- EBP and EBG were found cytotoxic as compared to control.

- EBP and EBG were found to be inhibiting TNF- $\alpha$.

- Barleria prionitis and Barleria grandiflora may be efficient members in controlling and treating oral infectious inflammatory ailments. 